International Journal of Current Advanced Research

ISSN: O: 2319-6475, ISSN: P: 2319 - 6505, Impact Factor: SJIF: 5.995

Available Online at www.journalijcar.org

Volume 6; Issue 4; April 2017; Page No. 3433-3438

DOI: http://dx.doi.org/10.24327/ijcar.2017.3438.0287

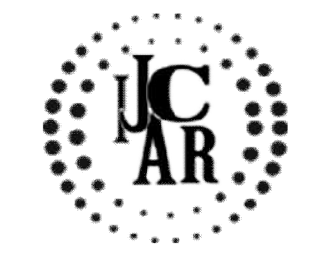

Research Article

\title{
DEVELOPMENT OF INTERNATIONAL TRADE ON THE BASIC OF EQUALITYAND MUTUAL BENEFIT
}

\author{
Cindawati \\ Faculty of Law, University Palembang of South Sumatera Indonesia Jl. Dharmapala No. 1A \\ Bukit Besar Palembang.30139
}

\section{A R T I C L E I N F O}

Article History:

Received $15^{\text {th }}$ January, 2017

Received in revised form $9^{\text {th }}$ February, 2017

Accepted $22^{\text {nd }}$ March, 2017

Published online $28^{\text {th }}$ April, 2017

\section{Key words:}

International trade, equality, mutual benefit.

\begin{abstract}
A B S T R A C T
The objective of this research is to describe and analyze the development of international business on the basis of equality and mutual benefit. The method used is normative juridical. The results of research: the development of international trade on the basis of equality and mutual benefit: to realize changes in the form of distribution of goods and services. The principle of reciprocity or reciprocity requires that the parties to the contract must exercise their respective rights and obligations on a reciprocal basis and the exercise of the contract should provide "mutual benefits". By establishing the principles of contract law: the principle of agreement, the principle of pactasuntservanda, Freedom of contract and the principle of equilibrium, are the factors that determine the equality of the parties namely "justice of exchange" that would be upheld. The contract ratio refers to the objective of a fair shift of property (gerechtvaardigde) and raises the legal consequences of the fairness of the parties' benefits and results in legal enrichment.
\end{abstract}

Copyright $₫ 2017$ Cindawati. This is an open access article distributed under the Creative Commons Attribution License, which permits unrestricted use, distribution, and reproduction in any medium, provided the original work is properly cited.

\section{INTRODUCTION}

The development of an era can not be separated from the development of business and technology. Because technology is something that supports business, a business is done for a profit such as in exchange for goods known as barter. Business or trade in goods from a country, to another country beyond the borders of the country that is meant by foreign trade or international trade. Similarly, the business or domestic trade that is doing transaction "sale and purchase", then in foreign trade also conducted activity "selling" called export and activity "buy" which is commonly called import. This sale and purchase transaction is also called trading. Exports and imports in this sense are limited to export and import of goods (visible goods). In general, domestic trade procedures are not different from foreign trade.International trade is a trade conducted by residents of other countries on the basis of mutual agreement. The intended population may be either an individual (individual with an individual), between an individual and a government of a State or a government of another country. Many countries engage in international trade business being one of the main factors to increase the national income by the amount of income received by household households in a country from the

\section{*Corresponding author: Cindawati}

Faculty of Law, University Palembang of South Sumatera Indonesia Jl. Dharmapala No. 1A Bukit Besar Palembang.30139 delivery of production factors within a regular period of one year ${ }^{1}$ In the economic field, Gross Domestic Product (GDP) is the market value of all goods and services produced by a country in a given period. GDP is one method of calculating national income. Generally trades are regulated through bilateral agreements between two States. As a result of these restrictive and protective policies creating barriers in the traffic of goods, services and capital between countries in Europe, they seek to control the countries of Asia and Africa in applying mercantilism. This led to economic and political life in Europe becoming increasingly widespread and concentrated on trading activities, not only local and regional trade between European countries but extending outside Europe. With legal norms that give freedom to economic actors in carrying out contracts, including the pursuit of profits as much as has been going on for a long time. The principle of freedom of contract is a principle, in the implementation of international trade. Trade in goods from a country, to another country beyond the borders of the country that is meant by foreign trade or international trade. Similarly, in the case of domestic trade of "buying and selling" transactions, foreign trade is also carried out "selling" activities called exports and "buy" activities, commonly called imports. Import export activities are based on the condition that no country is truly self-sufficient because each other needs each other and is complementary. Each country has

${ }^{1}$ https://id.m.wikipedia.org/wiki/produk_domestik_brutodiaksestanggal

12Desember 2016 
different characteristics, both natural resources, climate, geography, demography, economic structure and social structure. These differences lead to differences in commodities produced by cost compositions that require quality or product quality. For that the author is interested to examine the development of international trade on the basis of equality and keuintungan along with this formulation

\section{Formulation of the problem}

What is the analysis of the development of international trade on the basis of equality and mutual benefit?

\section{RESEARCH METHODS}

The method applied is normative juridical, which is guided by the rules of law contained in the legislation, or set a certain standard or norm on a phenomenon by reviewing secondary data or bibliography. Hereinafter divided according to legal sources as follows: primary law material consists of legislation, secondary law material consists of relevant libraries, and tertiary legal material consists of legal dictionaries. The qualitative approach does not utilize statistical and arithmetic data ${ }^{2}$

Research Objectives to be achieved in this research is to explain and analyze the development of international business on the basis of equality and mutual benefit.

\section{DISCUSSION}

Laws governing commercial relationships of a civil nature relating to different countries. The elements:

1. International trade law is a set of rules governing commercial relationships of a civil nature.

2. These legal rules govern different transactions of the State.

The development of international trade or business on the basis of common equality and mutual benefit is an important element in the promotion of friendly relations between countries. Based on the view that the establishment of a uniform arrangement that will govern contracts for the sale of international goods taking into account social, economic, and legal system differences will contribute to eliminating various constraints and legal barriers to contracts in international trade or business ${ }^{3}$

The purpose of the International Trade Law is: not unlike the GATT (General Agreement on Tariffs and Trade 1947) objective in the preambule. Objectives: a. To achieve stable international trade and to avoid national trade policies and practices that harm other States.

1. To increase the volume of world trade by creating trade

2. Which is attractive and beneficial to the economic development of all States.

3. Improve the standard of living of mankind and

4. Increase employment.

${ }^{2}$ Peter Mahmud Marzuki, PenelitianHukum, EdisiPertama, Cet. Kedua, Jakarta: Kencana, 2006, halaman 141.

${ }^{3}$ In the prevailing international trade practice, implementation shall be governed in a bilateral business contract (Bilateral Agreement) or in the standard set by the Convention agreed with the countries, such as in the trade agreements regulated by the World Trade Organization (WTO).
5. To develop a non-sovereign multilateral trading system of a State Certain to implement open and fair trade policies that benefit all countries.

\section{Description of International Trade Practices and cases}

Based on the Marketing and Offering there is an International Trade Contract (Export-Import) with the determination of delivery of goods and payments to be obeyed by both parties. In international business transactions conducted by the seller (exporter) and the buyer (importer) will arise rights and obligations for each party. The exporter shall be obligated to deliver the goods and shall be entitled to receive payment for the delivery of the goods. On the other hand, the importer shall pay the price of the goods and shall be entitled to demand the delivery of goods purchased. In carrying out international trade transactions, most exporters and importers need the financing ${ }^{4}$ from external sources. For exporters, financing is called export financing, primarily needed to cover their working capital needs before or after shipment of goods. Prior to shipment of goods, exporters need funds to finance the production ${ }^{5}$ or collection of goods ordered by importers. Short-term financing is financing for a period of less than one year. They also need funds to finance the inventory of goods stored in the warehouse before the order is received from abroad or goods dispatched.

The above exposes indicate that in the inter-state (transnational) trade-purchase there are various provisions binding on both parties (exporter-importer), or in other words that after the trade contract is agreed upon by both parties, Arising laws or laws that apply only to the parties binding on international trade agreements or contracts.

The import-export transactions are the businessmen between countries, then in its implementation, necessarily require comprehensive requirements, which inevitably attract the attention of international institutions or institutions concerned about the progress of international business, and international economic cooperation both regionally and internationally.

The development of business transactions is a challenge to the International Trade Law. This field of law to accommodate this rapid development through its legal rules.Indispensable for traffickers for legal certainty. While getting legal protection. With the development of science and technologyincreasingly advanced in the era of technology and information age. In regards to monopolistic practices and anticompetitive strategies.

The technological era in which technological times become unlimited income benchmarks because the better the quality of a technology will create an infinite passive income from being created and generating royalties Example: today Bill gates Microsoft's owner Microsoft ${ }^{6}$ corporation is a United States multinational corporation that develops, makes, licenses, and supports a variety of computer-related products and services that earn US \$ 73.72 billion in 2012. In 2016 Bill Gates wealth reached 90 billion US dollar or equivalent

${ }^{4}$ SiswantoSutojo, MembiayaiPerdaganganEksporImpor, PT DamarMulia Perkasa, Jakarta, 2001, hlm 116.

${ }^{5}$ SiswantoSutojo, MembiayaiPerdaganganEksporImpor, PT DamarMulia Perkasa, Jakarta, 2001, hlm 116.

${ }^{5}$ Ibid

6“"Microsoft Visitor Center Student information: key Events in Microsoft History. Diaksestanggal 12 Desember 2016 
around $\mathrm{Rp} 1.188$ trillion. The company also produces a series of software for desktop and server, active in several fields such as internet search. And hand phone. Certainly by creating a computer technology that is currently growing and will continue to create a continuous royalty for Bill Gates ${ }^{7}$ Critics have begun to accuse Microsoft of monopolistic practices and anti-competitive strategies including the denial of binding approval, undertaking unrepresentative marketing tactics, both the US Department of Justice and the European Commission declaring the company to violate antitrust laws. ${ }^{8}$ The information age In the 1990s that began the era of information continues to grow rapidly until the speed of the world of information will hold full in the development of the business world in the future from small to large industry, home to factory, shop, school, organization, marketing and much more. Will require speed in business delivery. In this case it is said through internet network / website that will always be ready to work for you 24 hours non stop without wages will work for you. For example, the world's largest online store with the first 10 trillion revenue within 3 years of career.

A contract is a legal institution that forms the basis of most business relationships including trading ${ }^{9}$ of property, service and employment transactions involving contracting agencies. Business interactions between business actors are mostly done through contracting agencies ${ }^{10}$

The definition of contract can be found in various literature:

1. Contract is an enforcement set of mutual obligations for which the law provides a remedy, recognizes a duty, or provides for court enforcement ${ }^{11}$

2. Contract is an agreement between two or more persons which creates an obligation to do or not to do a particular thing ${ }^{12}$

3. Contract is promise or set of promises that the courts will enforce ${ }^{13}$

4. Contract is a transactions involving two or more individuals whereby each of them obliges to other, with reciprocal rights to demand performance of what is promised by each respectively ${ }^{14}$

5. Contract is alegally binding agreement made between to or more persons, by which the rights are acquired by one or more to acts of forbearances on the part of the others ${ }^{15}$

From these definitions can be taken several characteristics, namely in the contract there are elements: promise (promise), agreement (agreement), mutual obligation (mutual

\footnotetext{
${ }^{7}$ https://id.mwikipedia.org>wiki>Bill_Gatdiaksestanggal 12 Desember 2016

${ }^{8} \mathrm{http} / /$ id.m.wikipedia.org/wiki/Micr. Diaksestanggal 12 Desember 2016

${ }^{9}$ F.williamMcCarty\&JohnW.Bagby, The Legal Environment of Business, (Irwin, 1990),

p. 212.

${ }^{10}$ AgusSardjono,yettyKomalasari,RosewithaIrawati,

TogiPangaribuan,PengantarHukumDagang, penerbitRajaGrafindoPersada,Jakarta, 2016, halaman 5 .

11. Mc.Carty, The Legal Environment of Business, ..... Op.Cit. p. 214

${ }^{12}$ Henry Campbell Black, Black's Law Dictionary, St. Paul Minn:West Publishing Co, 1979, p. 291-292

${ }^{13}$ David Reitzel,et.al., Cotemporary Business Law, Principles and Cases, $4^{\text {th }}$ ed.,

Mc.Craw-Hill Bokk Company, 1986, p.142.

${ }^{14}$ Steven H.Giffis, Law Dictionary, (Baron's Educational Series, 1991),p. 97

${ }^{15}$ Anson in PaulH.Richards, Law of Contract, $4^{\text {th }}$ ed., Financial Time Pitman Publishing, 1999, p.9.
}

obligation), which can be imposed implementation through the law (legally enforceable) ${ }^{16}$

When compared between the definition of the contract with the understanding of the engagement sourced from the agreement is basically the two concepts have similarities and similarities that lie on the element agreement (agreement), which gave birth to the obligation in a mutual (mutual obligation). A contract is an agreement between two persons orMore that bind themselves to do something or not to do something, whose implementation can be imposed through the judicial tool (judicial institution) ${ }^{17}$ The Contract is an expression or reflection of the aspirations of the parties (business actors) for the protection of the rights and interests of both parties, with Sanctioned norms for the defendant. This binding provision has been strictly regulated since the contract was agreed (signed) by both parties, such as from the start of the preparation of the delivery of goods requiring funds for preparatory activities up to shipment, the risks in transit, so that all of them are implemented with the payment of the buyer (importer). All clear and detailed in the business contract must begin with the precision of each party to study the contract clause, which is generally based on contract or standard agreement (standard). The carefulness and prudence of each side is a wise anticipatory factor. In the realization of a "fair" International Business Law requires a principle or principle that guarantees the rights and interests of both parties. The principle in question is the "Balance Principle", which is relatively understandable to the general view of craving for peace and justice ${ }^{18}$

\section{Nature of Relationship with International Trade}

The objective expectation in the formation of the covenant, the formation of the will of the one who acts through the formation of hope plays an important role, although will is a "subjective will" but not a will with selfish intentions. Anything that affects the formation of the will, it is not merely the motive of the parties that can be revealed, but includes also the motives known to the opponent, even if the motive is not visible. The higher the expectation, the more it leads to the expansion in principle the scope and quality of the obligations of parties that bind themselves to the agreement, with the aim that the will formed formed in harmony with the intent and purpose of the parties. In the context of an objective future expectation, an attempt to prevent the disadvantage of either party in the agreement. The foundation of the minds of the parties can be known if the future expectation is objective or in fact contains the sacrifice of the opposing party resulting in such, so that the future hope is not on the imbalance. The principle of equilibrium is based on achieving a balanced state as a result of which it must bring about the legitimate transfer of wealth Parties' Equality of factors that may disrupt the balance of the treaty are: the manner of establishing agreements involving unequal parties or inequalities of mutually reciprocal achievements In principle by grounding themselves on the principles of contract law such as the principle of agreement, The principle of pactasuntservanda, the principle of freedom of contract and the principle of equilibrium, the factors that determine the

\footnotetext{
${ }^{16}$ AgusSardjono,yettyKomalasari,RosewithaIrawati,

TogiPangaribuan,PengantarHukumDagang....., Op.Cit, halaman 6.

${ }^{17}$ Ibid

${ }^{18}$ ibid
} 
equality of the parties of "justice of exchange" 19 of the treaty is to be upheld. As long as achievements are promised reciprocal presupposes equality, in the event of an imbalance, attention will be given to the equality associated with the way in which the agreement is formed, and not on the ultimate outcomes offered on a reciprocal basis. In the Law of Business Contract or International trade there must be a Balance or equivalence or similarity between the seller and the buyer as it will greatly affect the contract. An agreement of two parties who promise one another, for certain both parties must agree, there is no element of coercion, pressure, deceit. In view of good faith from the agreement made, the agreement and if there is a dispute. With reciprocity (reciprocity or reciprocity), there is mutual agreement, and the objective of any binding agreement that must be obeyed in order to protect the parties equally.

In a business contract is the most important instrument for realizing changes in the form of distribution of goods and services. The contract's rationale refers to the objective of a fair shift of property (gerechtvaardigde) and raises the legal consequences of a fair share of the parties' profits (the agreement in principle leads to legal enrichment).The principle of balance in ordinary language is interpreted as a balanced word (even wicht) refers to the notion of a "loadsharing state on both sides being in a balanced state". The second consideration goes into the realm of legal philosophy that seeks to find the answer to the rationale of the binding force. The principle of equilibrium is grounded in the pursuit of a balanced state which as a result of it must bring about a legitimate transfer of wealth. The principle of reciprocity or reciprocity requires that the parties to the contract must exercise their respective rights and obligations on a reciprocal basis. Under this principle contract implementation should provide "mutual benefits", one party should not merely perform unbalanced achievements. In principle where there is a right of a party, there is the obligation of that party, vice versa. Reciprocal achievement (reciprocity or often called reciprocity) arises because of mutual agreement, and the goal is any binding agreement and must be obeyed in order to protect the parties in a balanced way.

In a reciprocal agreement ${ }^{20}$, there should be a fair surrender of the material to each other. The obligation of either party is faced with the obligations of the other party. The nature of reciprocity in a single agreement is an important concept to understand the feasibility of exchange. In a treaty of pleasure and responsibility (iusten en lasten) must be equally divided. In a buy-sell agreement, the buyer must pay the selling price as a means to get the goods. Thus the seller's obligation is to deliver the goods, which is the purchase price. The justification for the obligations of either party may be found in the obligations of either party, on the contrary imposed on the other side.

From time immemorial, the parties are bound by a mutually binding mutual will to achieve a common goal, as long as the content and contents of the agreement are not prohibited by law and requirements that have binding power, then the business contract will adhere to the principle of balance that

\footnotetext{
${ }^{19}$ In principle, based on the principles of contract law such as: the principle of agreement, the principle of pactasuntservanda, the principle of freedom of contract and the principle of equilibrium, the factors that determine the equality of the parties of "justice exchange" agreement that would be upheld.$$
{ }^{20} \text { Ibid }
$$

seems Has ensured or promised that the business agreement will be fair to both parties.

In international trade transactions conducted by the seller (exporter) and the buyer (importer) will arise rights and obligations for each party. The exporter shall be obligated to deliver the goods and shall be entitled to receive payment for the delivery of the goods. On the other hand importers are required to pay the price of goods and have the right to demand the delivery of goods purchased. In carrying out these international trade transactions, most exporters and importers require such financing to be called export financing, primarily required to cover their working capital needs before or after shipment of goods. Prior to shipment of exporter goods requires funds to finance the production or collection of goods ordered by importers. Short term financing is defined as financing for a period of timeless than one year. They also need funds to finance the inventory of goods stored in the warehouse before the order is received from abroad or goods dispatched.

Case: Short Term Financing Guaranteed Commodities ${ }^{21}$

Shipments or Bill of Lading serves as a sign of ownership of shipped goods. Therefore, if the exporter is pressed for funding needs and can not wait for payment from overseas buyers.

For example, the Negotiable Bill of Lading case, exporters can "negotiate" the bill of lading of goods they export to a bank or non-bank financial institution at a discount (lower price of $\mathrm{L} / \mathrm{C}$ due to reduced deposit interest). The exporter negotiating the bill of lading delivers the right of ownership of the goods to the bank or non-bank financial institution, which provides the loan or purchases the shipment documents. Thus the bank has ownership rights over the exported goods. The subsequent fund disbursement process is the Bank or the nonBank Financial Institution concerned shall submit the bill of lading, the draft of the exporter (notes) and other documents to the importer. Then means of payment with Letter of Credit (L/C) issuing bank, provided that the $\mathrm{L} / \mathrm{C}$ importer pays or accepts draft receipt of bill of lading and other documents. Furthermore, importers remove goods from the port. If for any reason the importer is unwilling to pay or approve a draft (draft), a Bank or a non-Bank Financial Institution that buys or provides a guarantee of negotiable bill of lading can collect goods from the port and sell it on the free market. If the amount of proceeds from the sale of the goods is insufficient to cover the loan amount, they may or may not charge the remainder to the exporter. This depends on the terms of the bill of lading guarantee agreement that has been agreed by both parties previously 22

In Harmonization ${ }^{23}$ with Balance Principles in International Business Contract Law:

There are three basic understanding of International Trade Contract Law:

a. Need understanding of contract law (agreement) of a Legal System of the parties. For example: Indonesian national law. This understanding of Indonesian

\footnotetext{
${ }^{21}$ SiswantoSutojo, MembiayaiPerdaganganEksporImpor, PT DamarMulia Perkasa, Jakarta, 2001, hlm 116.

${ }^{22}$ Ibid

${ }^{23}$ Huala Adolf,Dasar-dasarHukumKontrakInternasional, Bandung: RefikaAditama, 2007, hlm. 30
} 
national law is relevant because it is one of the main legal sources chosen by the parties to govern the contract.

b. Require an understanding of International civil law) in situations of legal conflict between the parties to the contract, then the role of the International Civil Law which will be used to determine the law to be applied to international contracts.

c. Need to understand the principles or rules of International Customary Law applicable in International Business Contract. The principle can be either written or unwritten. Acknowledging the Principles of International Business Law, Law there are several similarities of the various National Law Systems in various countries that only touch the substance in general, every National Law has its own rules. Such circumstances are not conducive to international business transactions because different rules wouldonly hinder the implementation of international business transactions that require sublimation and certainty.

The essential purpose is derived from the harmony ${ }^{24}$ principle: to achieve a balance between self-interest and the related interests of the other side. A business contract is the most important instrument for realizing changes in the form of distribution of goods and services. The contract's rationale refers to the objective of a fair shift of property (gerechtvaardigde) and raises the legal consequences of a fair enrichment of the parties (the agreement in principle leads to legal enrichment).

In international contracts especially those involving large funds and related to the construction of an infrastructure, the overmacht clause includes earthquakes, demonstrations, and wars. The load of events belonging to the overmacht, for example, natural disasters such as tsunami floods or other natural disasters, are generally accepted, recognizing the principle of International Contract Law in various countries. For example: an international trade practice that strongly desires this harmonization of the law in the field of transportation, whether sea, land, or air. Traders acknowledge the harmonization of good law between countries in the world regarding the law in this field, to be able to run smoothly and surely.

\section{CONCLUSIONS}

The development of international trade on the basis of equality and mutual benefit:

1. To realize changes in the form of distribution of goods and services. The Principle of Reciprocity or reciprocity requires that the parties to the contract must exercise their respective rights and obligations on a reciprocal basis and the execution of the contract must provide "mutual benefits"

2. By relying on the principles of contract law: the principle of agreement, the principle of pactasuntservanda, the principle of freedom of contract and the principle of equilibrium, are the factors that determine the equality of the parties namely "justice of exchange" that will be upheld.
3. The contract's ratio refers to the objective of a fair shift of property (gerechtvaardigde) and raises the legal consequences of equitably taking advantage of the parties and resulting in legal enrichment.

\section{Acknowledgements}

We would like to thank the local government and the central government of Indonesia. Special thanks to the school authorities and the subjects that participated in the studies we valued.

Declaration conflict is interesting: there is no conflict of interest of author

Funding: this study does not receive grants from the funding agencies.

\section{Contribution Author:}

Cindawati: Conceptual in research, data collection, manuscript design, script review, interpretation of results.

\section{Reference}

\section{Buku}

AgusSardjono, YettyKomalasari, RosewithaIrawati, TogiPangaribuan, PengantarHukum Dagang,p enerbit Raja GrafindoPersada, Jakarta, 2016

Adolf Huala, HukumPerdaganganInternasional, PT Raja GrafindoPersada, Jakarta, 2005

AdolHuala, Dasar-dasarHukumKontrakInternasional, RefikaAditama, Bandung, 2007

Anson inPaulH.Richards, Law of Contract, $4^{\text {th }}$ ed., (Financial Time Pitman Publishing, 1999.

David Reitzel,et.al., Cotemporary Business Law, Principles and Cases, $4^{\text {th }}$ ed., Mc.Craw-Hill Bokk Company, 1986.

F.williamMcCarty\&JohnW.Bagby, The Legal Environment of Business, (Irwin, 1990)

HannuHonka, Harmonization of Contract Law Through International Trade A Nordic

Perspective, Tulane European and Civil Law Forum, 1996

Henry Campbell Black, Black's Law Dictionary, St. Paul Minn:West Publishing Co, 1979

Grace Xavier, "Global Harmonisation of Contract Laws", 20 (1) Const. L.J., 2004

Steven H.Giffis, Law Dictionary, Baron's Educational Series, 1991

SoedjonoDirdjosisworo, Pengantar Hukum Dagang Internasional, RefikaAditama, Bandung, 2006

SiswantoSutojo, MembiayaiPerdaganganEksporImpor, PT DamarMulia Perkasa, Jakarta, 2001

Wayne R. Barnes, “Contemplating A Civil Law Paradigma for a Future International

Commercial Code”, Louisana Law Review 677, 2005

Peter Mahmud Marzuki, PenelitianHukum, EdisiPertama, Cet. Kedua, Jakarta: Kencana, 2006

PeraturanPerundang-undangan

ICC (International Chamber of Commerce)

Incoterm (The International Commercial Terms)

UCP (The Uniform Customs and Practice for Documentary Credits)

WTO (World Trade Organization) 
UNIDROIT (The International Institute for the Unification of Private Law)

GATT (General Agreement on Tariff and Trade)

PECL (the Principles of European Contract Law).

CISG, 1980 (The United Nations Convention on Contracts for the International Sale of Goods)
Internet

https://id.m.wikipedia.org/wiki/produk_domestik_brutodiak sestanggal12 Desember 2016

https://id.mwikipedia.org>wiki>Bill_Gatdiaksestanggal 12

Desember 2016

http//id.m.wikipedia.org/wiki/Micr. Diaksestanggal 12

Desember 2016

\section{How to cite this article:}

Cindawati (2017) ' Development Of International Trade On The Basic Of Equality and Mutual Benefit', International Journal of Current Advanced Research, 06(04), pp. 3433-3438.

DOI: http://dx.doi.org/10.24327/ijcar.2017.3438.0287 